\title{
SPATHULATE HEAD SETAE ON THE LARVA OF CHAMYRIS CERINTHA TREITS.
}

\author{
BY HARRISON G. DYAR, WASHINGTON, D. C.
}

I had occasion to notice spathulate head setae in the case of Cicinnus melsheimeri (Journ. N. Y. ent. soc., iv, 92). A second instance is found in Chamyris cerintha, though here it is the first epicraneal seta that has become flattened instead of the fourth, and the structure disappears at the last moult. A condensed description of the last stage of the larva has been given by Mr. Coquillett (Papilio i, 56); but he does not refer to the spathulate hairs of the early stages. I assume the number of stages for convenience in indicating them; I do not know that seven is the true number.

Stage IV. Slender, anal feet divergent: head strongly bilobed, the lobes angular, the apex black with a line passing down both front and back lateral angles; green; seta $i$ short, spathulate; width $\mathrm{I.2} \mathrm{mm}$. Body with joint I2 slightly enlarged; setae single, stiff, coarse, black; i, ii, iii, v, pointing sharply forward, iv and vi backward, all normal, seta iv behind the middle of the spiracle; leg shields small with few setea. Green; tubercle $i$ on joints 5 to 7 enlarged and black; an obscure white lateral line above wart iii; anal feet and a subventral dash on joint 12 , crimson. The two anterior pair of abdominal feet are slightly weaker than the others.

Stage $V$. The same; a broken reddish line runs along warts $i$ and $i i$, which are nearly in line; white lateral line distinct.

Stage VI. The same; the white lateral line is sharply edged; head green, the black lines fainter than before, seta i still spathulate.

Stage VII. Head more rounded, seta i no longer spathulate, very short; the lobes are low, not angular. Body slender, dorsum between the distinct white lateral lines filled in with dark vinous purplish, the subventral regions green. Setae coarse, long and black; tubercle $\mathrm{ii}$ on joint $\mathrm{I} 2$, and $\mathrm{i}$ on $\mathrm{I}_{3}$ large, high and conical, the others normal.

The line on the head is abbreviated, partly or wholly brown; width $2.5 \mathrm{~mm}$. Abdominal feet essentially equal.

Food plants. Wild cherry and plum.

Larvae solitary, very active and quickly spring off of the plant when disturbed, like some Deltoids.

\section{AN APPAREN'TLY NEW LECANIUM FOUND ON WHITE CEDAR.}

\section{BY T. D. A. COCKERELL AND G. B. KING.}

This article is written by Mr. Cockerell, but is partly based on Mr. King's notes and observations.

When Mr. King sent me a small almost globose Lecanium found on White Cedar, I could hardly believe it could be anything but a form of $L$. Aletcheri, especially since he had found some veritable fletcheri in Massachusetts on arbor-vitae. A close examination of the Cedar scale, however, reveals differences which must surely be specific, so the insect is described herewith. 

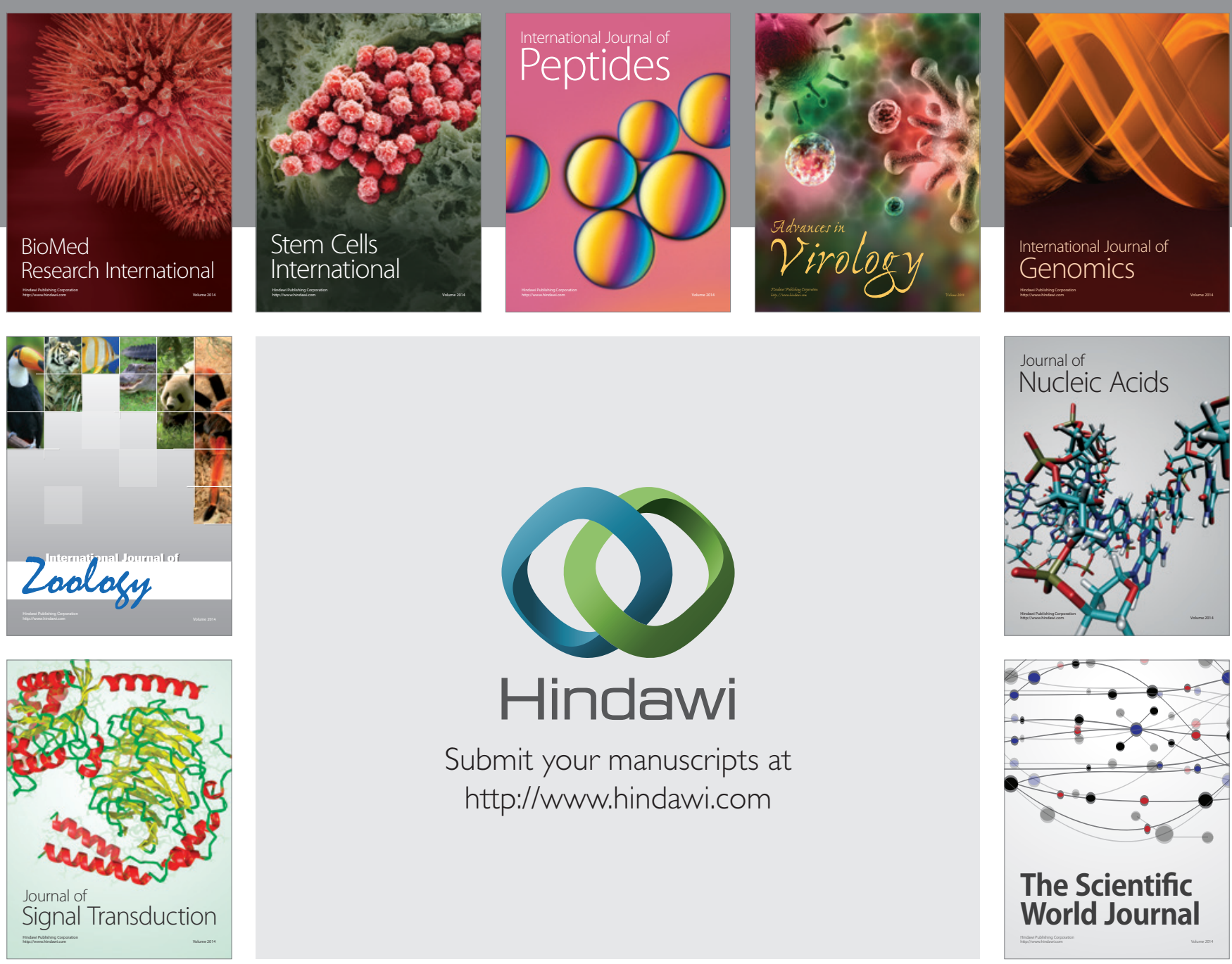

Submit your manuscripts at

http://www.hindawi.com
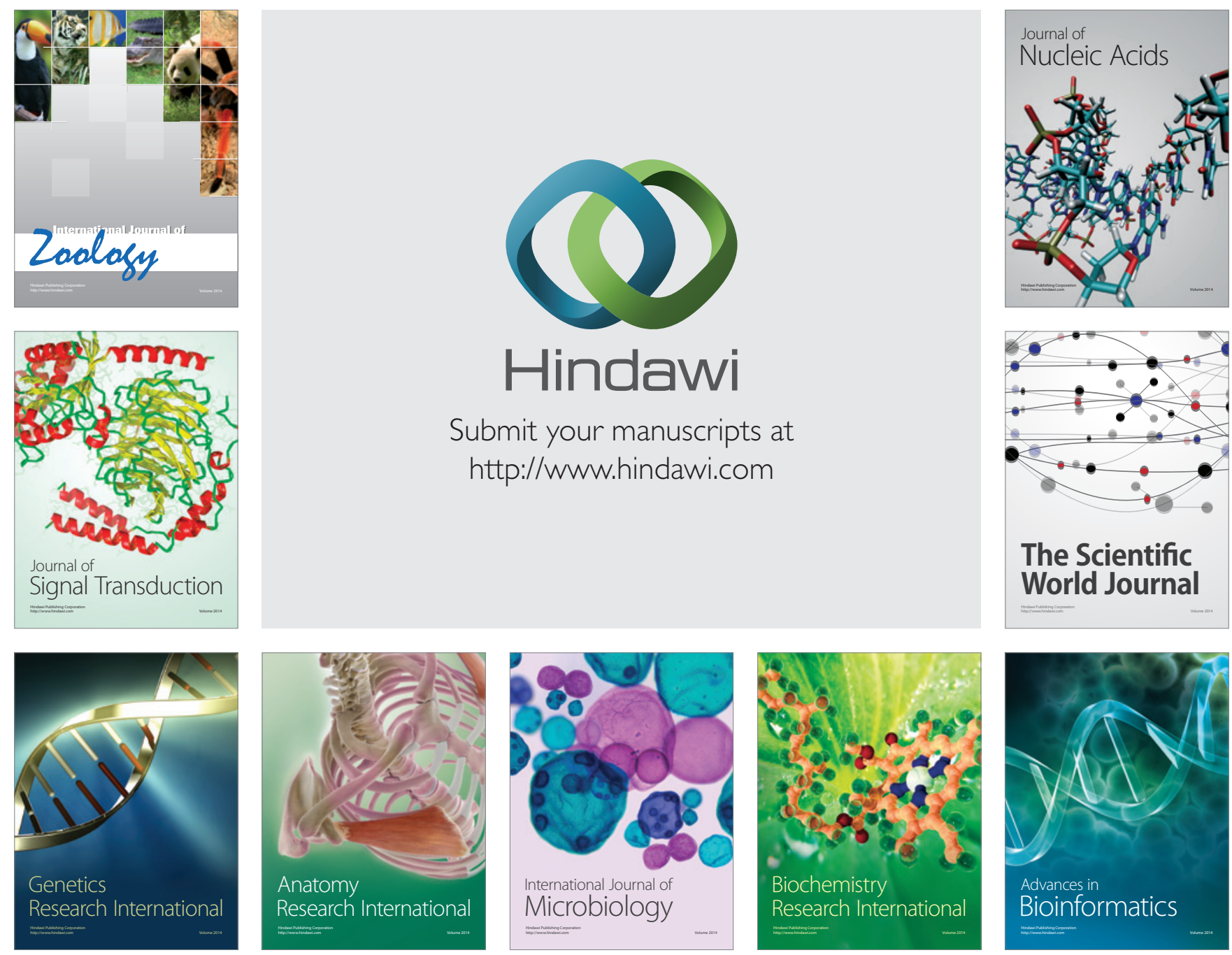

The Scientific World Journal
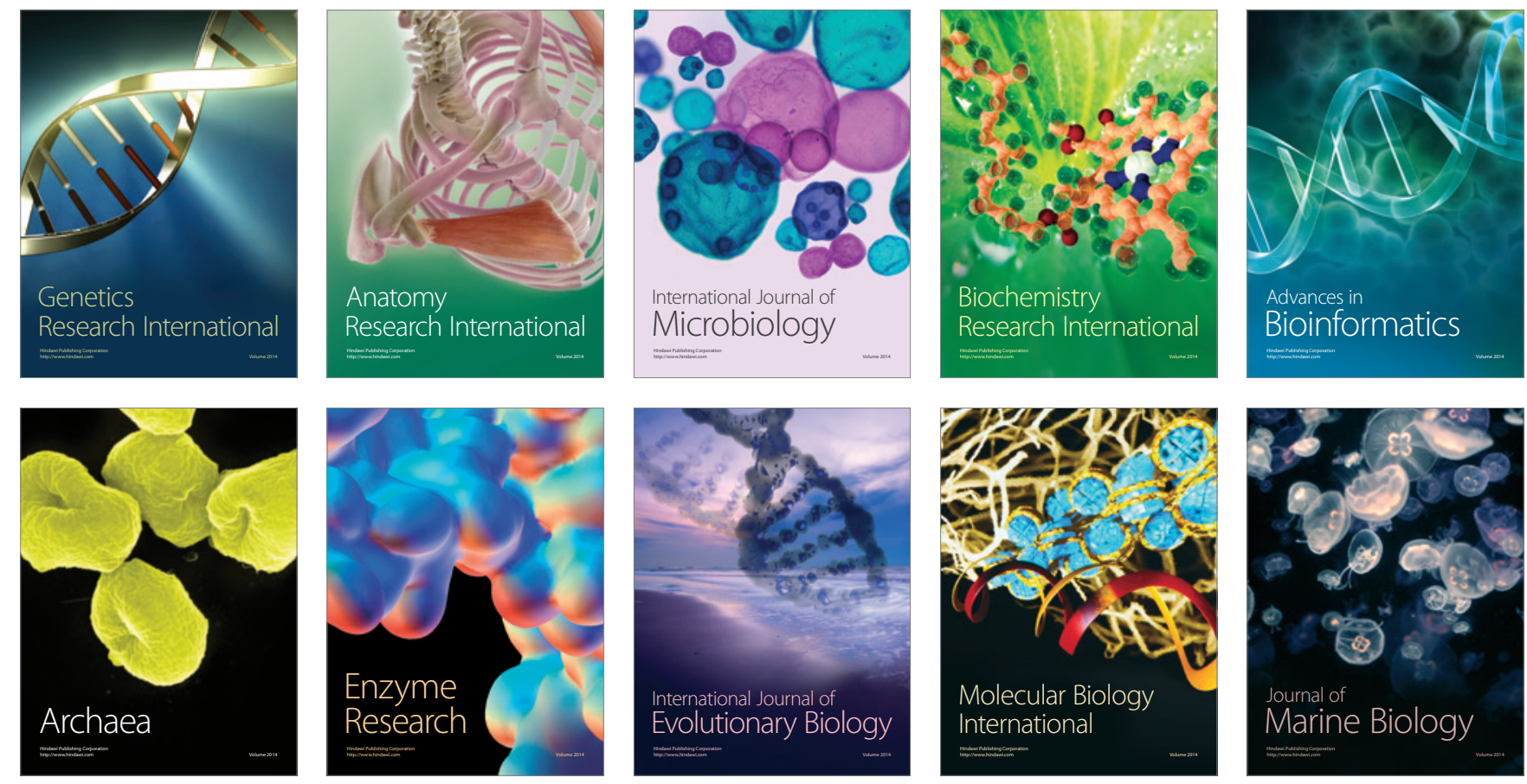